\title{
NILAI EDUKASI MITOS DAN RELEVANSINYA DENGAN PENANAMAN NILAI PADA KELUARGA MINANGKABAU KONTEMPORER: TINJAUAN AWAL
}

\author{
Yunarti $^{1}$, Winda Rahmadani ${ }^{2}$
}

\begin{abstract}
J oseph Campbell explains one of the four mythical functions is a pedagogic function that is how humans live life as human beings under any circumstances. Some forms of folklore with pedagogic educative function are as a tool or complement in education and enculturation values such as stories to educate children disciplined, obedient, diligent and intelligent. The enculturation process to ensure the individual achieves maturity and cultural maturity so as to support the social order. In addition to the family as the first institution for the enculturation values in children, the social environment system that becomes interaction area will also affect each other's attitude and parenting ways and the environment. From the preliminary research, it was concluded that the observed myths of education were no longer present in the daily lives of the five families of informants. On the 5 myths traced, only the Malin Kundang myth is still well known. The substance of the values contained in the myth is accepted but is considered to be no longer to be found in the realities of everyday life. In the changing context, the enculturation process of the Minangkabau has shifted along with the swift entry of new values through new communication media
\end{abstract}

Keywords: Myth, Education, Enculturation, Minangkabau Contemporary

Abstrak

Joseph Campbellmenjelaskan salah satu dari 4 fungsi mitos adalah fungsi pedagogik yaitu bagaimana manusia menjalani hidup sebagai manusia dalam kondisi apapun. Beberapa bentuk folklor dengan fungsi pedagogik edukatif adalah sebagai alat atau pelengkap dalam mendidik dan penanaman nilai-nilai seperti ceritera-ceritera untuk mendidik anak-anak berdisiplin, patuh, tekun dan cerdas. Proses penanaman nilai tersebut untuk memastikan individu mencapai kedewasaan dan kematangan budaya sehingga menjadi pendukung tatanan sosial tersebut. Selain keluarga sebagai pranata pertama penanaman nilai pada anak, sistim lingkungan sosial yang menjadi arena interaksi tersebut juga akan saling mempengaruhi sikap dan cara pengasuhan orangtua dan lingkungannya. Dari riset awal yang dilakukan disimpulkan bahwa cerita mitos edukasi yang diamati tidak lagi hadir dalam keseharian lima keluarga informan. Dari 5 mitos yang ditelusuri, hanya mitos Malin Kundang yang masih cukup dikenal. Substansi nilai yang terkandung dalam mitos diterima namun dianggap tidak lagi dapat ditemukan dalam realitas kehidupan seharihari. Dalam konteks yang berubah, proses penanaman nilai-nilai keminangkabauan telah bergeser bersamaan dengan derasnya masuk nilai-nilai baru melalui media komunikasi baru.

Kata Kunci : Mitos, Edukasi, Penanaman Nilai, Minangkabau Kontemporer

\footnotetext{
${ }^{1}$ Penulis adalah dosen tetapJurusan Antropologi FISIP Universitas Andalas

${ }^{2}$ Mahasiswa Jurusan Antropologi FISIP Universitas Andalas

Nilai Edukasi Mitos dan Relevansinya
} 
A. Pendahuluan

M itos, dalam kajian folkloristika adalah kisah suci yang menjelaskan bagaimana dunia maupun manusia dapat terbentuk seperti sekarang ini. Secara populer mitos sering juga disebut sebagai mitologi yang diartikan sebagai kajian tentang mitos atau dapat juga diartikan sebagai himpunan atau koleksi berbagai mitos. Dalam pengertian yang lebih luas, istilah mitos tersebut dapat mengacu kepada cerita tradisional, legenda maupun cerita rakyat.

Berbeda dengan mitos yang sering dikaitkan dengan kesucian peristiwa dan tokoh cerita, peristiwa dan tokoh dalam cerita rakyat tidak dianggap sebagai kisah suci yang dipercaya kebenarannya sedangkan pada legenda pelaku-pelakunya adalah manusia biasa dan seringkali juga kejadian dan peristiwanya dianggap benarbenar terjadi.

Joseph Campbell ${ }^{3}$ menjelaskan salah satu dari 4 fungsi mitos adalah fungsi pedagogik yaitu bagaimana manusia menjalani hidup sebagai manusia dalam kondisi apapun ${ }^{4}$. Beberapa bentuk folklor dengan fungsi pedagogik edukatif adalah sebagai alat atau pelengkap dalam mendidik dan penanaman nilai-nilai seperti ceriteraceritera untuk mendidik anak-anak berdisiplin. Ceritera-ceritera binatang untuk mengajarkan kedisiplinan, kepatuhan, kecerdasan, ketekunan dstnya. Cerita Kak Kancil yang ulet dan cerdik dan cerita Malin Kundang adalah contoh cerita rakyat yang diacu sebagai alat edukasi dalam masyarakat adat Minangkabau. Melalui cerita rakyat sejenis itu, masyarakat membentuk karakter anak menjadi dewasa dengan kepribadian yang mendukung tatanan nilai yang telah mapan yang

${ }^{3}$ Campbell, Joseph (1990). The Hero's Journey: Joseph Campbell on His Life and Work (first edition, 1990 ed.). pp. 52-53

44 fungsi mitos: fungsi mistis; ungkapan kekaguman terhadap alam semesta, fungsi sosiologis; mendukung dan mengesahkan tata tertib sosial, fungsi kosmologis; menjelaskan bentuk alam semesta dan fungsi pedagogis tentang bagaimana manusia mengembangkan kemampuan untuk dapat bertahan hidup dalam kondisi apapun. Alan Dundes menjelaskan ada 5 fungsi mitos.

$56 \mid \mathrm{P}$ a g e terefleksi dalam sistim dan pola pengasuhan.

Mempertahankan keberlangsungan dan keteraturan tatanan sosial adalah salah satu insting individu manusia sebagai anggota masyarakat dengan cara menanamkannya kedalam diri individu sejak bayi hingga individu tersebut mati. Proses penanaman nilai tersebut untuk memastikan individu mencapai kedewasaan dan kematangan budaya sehingga menjadi pendukung tatanan sosial tersebut. Pada tahapan awal penanaman nilai akan berlangsung dalam keluarga sebagai lingkungan sosial pertama yang ditemui individu anak. Individu baru yang ditemui anak seperti ibu, ayah dan lingkungan dalam keluarga itu akan menjadi subjek sosial yang kelak akan membentuk karakter dan kepribadian dasar anak dengan orang-orang lain dalam lingkungan sosial yang lebih luas. Pada sisi lain, sistim lingkungan sosial yang menjadi arena interaksi tersebut juga akan dipengaruhi oleh sikap dan cara pengasuhan oleh orangtua dan lingkungannya.

Sistim lingkungan sosial yang homogen memungkinkan bertahannya pola pengasu han yang sama dalam jangka waktu yang panjang. Namun, dalam masyarakat yang heterogen mempertahankan pola asuh yang sama dan konsisten adalah hal yang sulit. Masyarakat adat hari ini terbuka dan terpapar dengan sistim nilai yang sangat beragam dan terkadang inkonsistensi satu sama lainnya. L. P. Hartley ${ }^{5}$ mengulas bahwa kehidupan seorang anak berada dalam dinamika perubahan dan komparasi yang ditandai ketegangan antara nilai-nilai makin sedikitnya tanggungjawab, bermain vs bekerja, waktu sekolah yang panjang, kurang terlibat dalam kehidupan sosial, intensitas hubungan tinggi dengan peer group dan tegangan antara tingginya tingkat konsumtif dibanding nilai-nilai produktif.

Untuk memahami fenomena pendidikan dan pola pengasuhan dalam kondisi dinamika yang mengikuti gerak perubahan sosial diberbagai dimensi seperti ekonomi, politik dan kebudayaan menuntut studi yang komprehensif. Tulisan ini bersumber dari studi yangtelah mencoba menelusuri guna memahami permasalahan pembentukan karakter anak dan pola asuh dalam keluarga

\footnotetext{
5 The Go-Between is a novel by L. P. Hartley published in 1953
}

Nilai Edukasi Mitos dan Relevansinya 
Minangkabau kontemporer sembari melihat kembali acuan normatif yang tersimpan dalam mitos dan cerita rakyat dalam budaya Minangkabau itu sendiri. Riset dilakukan di Kecamatan Pauh Kota Padang.

Kecamatan Pauh merupakan salah satu Kecamatan dari 11 Kecamatan yang terdapat diwilayah administratif kota Padang. Wilayah ini berada di kawasan barat kotaPadang pada posisi 0058 'dan 100021 ' 1 ' bujur timur dengan 10-1600 meter diatas permukaan laut dan suhu berkisar $220 \mathrm{C}=31,7 \quad 0 \mathrm{C}$. Ibu kota kecamatan Pauh terletak di kelurahan Cupak Tangah. Sementara kecamatan ini sendiri berbatasan langsung dengan kecamatan Koto Tangah di sebelah utara, kecamatan Lubuk Kilangan dan Lubuk Begalung di sebelah selatan, dengan kabupaten Solok di sebelah timur, kecamatan Kuranji dan Padang Timur di sebelah Barat.

Luas wilayah keseluruhan kecamatan ini adalah 146,29 km 2 atau lebih kurang $21,05 \%$ dari luas wilayah kota Padang. Kecamatan Pauh terbagi ke dalam 9 kelurahan bertopografi dataran tinggi dan perbukitan serta merupakan kawasan hutan negara berdasarkan UU no.41 tahun 1999. Kelurahan dengan wilayah terluas di Kecamatan Pauh adalah Lambung Bukit, yakni $38,80 \mathrm{Km} 2$, sedangkan Kelurahan Binuang Kampung Dalam memiliki luas wilayah yang relatif kecil, yakni2,97km².

\begin{tabular}{|c|c|}
\hline Kelurahan & Luas $\left(\mathrm{km}^{2}\right)$ \\
\hline Pisang & 3,99 \\
\hline Binuang Kp Dalam & 2,97 \\
\hline Piai Tangah & 4,97 \\
\hline Cupak Tangah & 2,99 \\
\hline Kapalo Koto & 35,83 \\
\hline Koto Lua & 18,92 \\
\hline Lambung Bukit & 38,80 \\
\hline Limau Manis Selatan & 12,96 \\
\hline Limau Manis & 24,86 \\
\hline Total & 146,29 \\
\hline
\end{tabular}

Sumber: Statistik Daerah Kecamatan Pauh 2016

Jenis lahan kering yang ada di Kecamatan Pauh adalah berupa tegal/kebun, ladang/huma, hutan rakyat, hutan negara,dan lainnya. Kecamatan Pauh kini disebut memiliki kelurahan yang telah berstatsus swasembada dalam artian setiap kelurahan memiliki kemampuan untuk mengolah dan memanfaatkan potensi yang terdapat di kelurahan masingmasing yang sesuai dengan tujuan pembangunan regional kota Padang. Jumlah penduduk kecamatan Pauh pada tahun 2015 adalah 68.448 jiwa yang terdiri dari 34.557 orang laki-laki dan 33.891 orang perempuan dengan 15.467 rumah tangga atau rata-rata berang gotakan 4,43 orang untuk setiap rumah tangga.Tingkat sebaran dan densitas penduduk kecamatan meningkat dari 443 jiwa/km2 perkelurahan di tahun 2013 menjadi rata-rata $468 \mathrm{jiwa} / \mathrm{km}^{2}$ pada tahun 2015 dengan laju pertumbuhan penduduk

Nilai Edukasi Mitos dan Relevansinya
2,68. Data tentang sebaran dan jenis pekerjaan tidak tersedia.

Kecamatan Pauh memiliki fasilitas pendidikan semua strata, mulai dari lembaga pendidikan Paud hingga perguruan tinggi, namun dalam dokumen Pauh Dalam Angka tidak terdapat informasi mengenai sebaran tingkat pendidikan masyarakat.Data mengenai fasilitas publik lainnya yang juga cukup mengesankan adalah bidang kesehatan. Terdapat satu puskesmas di kecamatan ini dengan 94 petugas medis dari dokter hingga perawat, lima puskesmas pembantu dan 70 pos layanan terpadu.

Pada tahun 2015 kecamatan Pauh memiliki 2.555 ha luas lahan sawah dengan total hasil panen padi 16.097 ton atau lebih kurang 6,3 ton .Sedangkan untuk produk palawija ubi kayu terdapat jumlah panen total 17,47 ton/ha. Produksi pertanian berupa sayuran kangkung merupakan komoditi pertanian yang paling banyak dihasilkan mencapai total 482,50 ton dan 
mentimun mencapai nilai produksi 385 ton dan sayuran bayam dengan nilai produksi 105,50 ton. Kecamatan Pauh juga terkenal dengan hasil produksi buah durian dan rambutan. Untuk tahun 2015 masing menghasilkan 1227 ton dan 410,72 ton

Merujuk pada hasil penelitian Adhitya Sapta Putra (2014) menjelaskan bahwa kecamatan Pauh yang terdiri dari 9 kelurahan jika dilihat berdasarkan adat terdiri dari tiga wilayah kenagarian yaitu Kenagarian Limau Manih (dahulunya bagian dari wilayah Lubuk Kilangan), Kenagarian Pauah Limo dan Kenagarian Pauah Sembilan (sekarang wilayah Kuranji).

Asal usul masyarakat Pauah konon dulunya berasal dari Solok Salayo ${ }^{6}$ yang meneruka lahan baru hingga sampai ke wilayah yang saat ini kita kenal sebagai kecamatan Pauh. Nenek moyang saat itu merupakan perwakilan dari 4 suku dari Solok yaitu Rajo Perak dari suku Jambak, Inyiak Sumbo dari suku Chaniago, Sanggono di Rajo dari suku Tanjuan dan Rajo Anggang dari suku Koto berjalan kaki melalui koto Alang sampai ke Banda Mua lalu menempuh perjalanan sampai ke Bukit Koto Tinggi. Konon dari puncak bukit ini yang dikenal dengan Camin Toran - mereka melihat dataran yang cukup luas antara wilayah yang sekarang merupakan kelurahan Lambuang Bukit, kelurahan Limau Manis Selatan, Ulu Gaduik dan Koto Tuo serta wilayah Pisang. Mereka melihat wilayah ini subur karena banyak dilintasi oleh aliran sungai yang salahsatunya kita kenal sebagai Batang Aia Kuranji.

Pada akhirnya saat para tetua nenek moyang itu memutuskan untuk menetap tidak hanya 4 nenek moyang tapi akhirnya juga bergabung nenek moyang dari suku Melayu yang dikenal bernama Rajo Putiah. Berlima, para nenek moyang mewakili suku Jambak, Chaniago, Tanjuang, Koto dan Melayu menjadi nenek moyang masyarakat asli Pauh dan dikenal sebagao "Balimo Nan Manih" (berlima yang manis/gagah). Nenek moyang ini juga membawa suku Bodi dan suku Piliang sehingga akhirnya menjadi 7 kelompok suku. Selain kelompok 7 suku yang kemudian menetap di wilayah Pauh yang kita sekarang, terdapat 7 kelompok dengan komposisi suku yang sama namun

${ }^{6}$ Emral Djamal Dt. Radjo Mudo menyebutnya dari Kubung Tigo Baleh

$58 \mid P$ a g e berbeda daerah asal. Kedua kelompok suku ini masing-masing menempati wilayah 'atas' (Tujuah nan di Ateh) dan wilayah di "bawah" (Tujuah nan di Baruah) dan saling berhubungan erat yang diibaratkan seperti dua orang bersaudara sehingga hubungan tersebut dikenal sebagai "Si Ampek Baleh".

Mengutip Emral Dt.Rajo Mudo, Putra (2014) menjelaskan bahwa jejak langkah Belanda dalam memperluas kekuasaan terhadap wilayah Pesisir Barat khususnya Bandar Padang mencapai wilayah Tujuah nan di Baruah atau Kuranji seperti yang kita kenal sekarang yang memicu pecahnya perang Rupik. Dalam pada masa itu, pejuang Tujuah Nan di Baruah terdesak sehingga mereka kemudian meminta pertolongan pada saudara mereka di Tujuah nan di Ateh.

Dalam perundingan musyawarah yang dilakukan oleh perwakilan Si Ampek Baleh, juga dihadiri oleh perwakilan dari Lubuak Kilangan dan Nagari XX Lubuak Bagaluang yang menghasilkan kesepakatan akan mengutus 2 orang pendekar dari suku Koto dan Jambak dari wilayah Tujuah nan Di Ateh. Meskipun tidak dijelaskan secara eksplisit apakah para pendekar ini berhasil memukul mundur Belanda ataukah tidak, namun kelompok Tujuah nan Baruah tetap menyampaikan penghargaan dan ucapan terima kasih mereka dengan mempersilahkan kedua pendekar beserta kerabatnya untuk tetap tinggal di wilayah Tujuah Nan di Baruah. Hal ini kemudian merubah komposisi jumlah kelompok suku dimana wilayah Tujuah Nan di Ateh berkurang menjadi lima kelompok suku sedangkan wilayah Tujuah Nan di Baruah bertambah menjadi sembilan kelompok suku. Musyawarah yang dilakukan di bawah pohon Pauh ini menghasilkan pergantian nama menjadi Pauah Sembilan menggantikan Tujuah nan di Baruah dan Pauah Limo menggantikan Tujuah nan di Ateh.

Saat ini Nagari Pauah sudah menjadi wilayah administratif kecamatan Pauah dan menjadi salah satu kecamatan yang cepat berkembang dan banyak didatangi oleh pendatang luar terutama karna kecamatan ini menjadi lokasi dimana universitas Andalas berada. Sejak tahun 1980-an, wilayah ini berubah dengan cukup cepat, berkembang menjadi wilayah sentra pendidikan tinggi yang memunculkan

Nilai Edukasi Mitos dan Relevansinya 
berbagai bisnis ikutan yang menghidupkan ekonomi masyarakat tempatan.

\section{B. Pembahasan}

1. Empat Cerita Mitos Minangkabau dan Nilai-nilai Edukasinya

$\mathrm{C}$ erita mitos yang dipilih dengan tekhnik purposive random sampling sesuai tujuan penelitian. 4 mitos yang akan dijadikan bahan acuan adalah mitos Malin Kundang, Sabai Nan Aluih-Mangkutak Alam, Rancak Di Labuah dan satu cerita fabel dalam kisah Asal Usul Nama Minangkabau. Pemilihan 4 mitos ini bukan didasari oleh prinsip representatif dari semua mitos yang dikenal di Minangkabau tapi lebih di maksudkan sebagai kajian dan analisis mitos yang individual sekaligus dengan nilai edukasi moral yang cukup universal.

Paradigma fungsionalisme adalah salah satu sudut pandang yang dapat digunakan untuk menganalisis sebuah mitos 7 . Perspektif fungsionalisme

${ }^{7}$ Paradigma lain yang juga populer adalah Analisis Strukturalisme Levi Strauss. Contohnya adalah kajian Ahimsa-Putra yang menerapkan model kajian struktural LeviStrauss untuk menganalisis karya sastra dan dongeng-dongeng dari wilayah nusantara, antara lain terhadap dongeng masyarakat Bajo berjudul

'Pitoto Si Muhamma'(2006: 99-180), karyakarya sastra Umar Kayam: Sri Sumarah, Bawuk, dan Para Priyayi,

dan Mitos Sawerigading dan Dewi Sri. Paradigma lain yang juga populer adalah kajian Semiotik dari Roland Barthes, bahwa didalam mitos terdapat tanda denotatif dan konotatif dan dibalik tanda-tanda tersebut terdapat makna yang misterius yang terdapat dalam komunikasi sehari-hari kita baik tertulis maupun melalui media cetak. Pendekatan lain yang juga familiar digunakan untuk menganalisis mitos adalah fungsionalisme strukturalmenekankan pada relasi fungsi yang memberikan penekanan pada struktur sosial. Dengan demikian, deskripsi mengenai struktur sosial sebagai konteks mitos, tidak kalah pentingnya dengan deskripsi atau pernyataan mengenai relasi fungsional itu sendiri. Analisis struktural lain yang juga populer digunakan adalah dari Alan Dundes yang menggunakan pemecahan Nilai Edukasi Mitos dan Relevansinya mengandaikan bahwa kehidupan sosiobudaya itu seperti tubuh makhluk hidup. Penganut aliran fungsionalisme ini percaya, bahwa analogi biologi (organisme) dapat digunakan untuk menjelaskan kehidupan sosio-budaya masyarakat (Kaplan, 1999: 77). Individu-individu maupun kebudayaan sebagai bagian dari masyarakat kemudian disejajarkan dengan sel-sel yang ada dalam tubuh makhluk hidup, yang selalu tergantung dan tidak terpisahkan dari fungsifungsi sel-sel lainnya. Layaknya tubuh makhluk hidup, kelangsungan kehidupan sosio-budaya dapat dipertahankan apabila individu-individu yang ada didalamnya saling bergantung dan berfungsi dengan individuindividu lainnya. Itulah sebabnya, perspektif ini memandang kehidupan sosio-budaya sebagai sesuatu yang harus selalu ada dalam keteraturan agar dapat bertahan hidup. Implikasinya, segala bentuk tindakan dan gejala yang dinilai mengancam keteraturan akan dianggap sebagai gangguan atau penyakit yang harus disembuhkan.

Ahli antropologi Bronislaw Malinowski dalam teori fungsionalismenya mengasumsikan adanya hubungan dialektis antara agama dengan fungsinya yang diaplikasikan melalui ritual. Secara garis besar, fungsi dasar agama diarahkan kepada sesuatu yang supernatural atau, dalam bahasa Rudolf Otto, "Powerful Other." Partisipan yang terlibat dalam sebuah ritual bisa melihat kemanjuran agama sebagai sarana meningkatkan hubungan spiritualnya dengan Tuhan karena pada dasarnya manusia secara naluriah memiliki kebutuhan spiritual. Teori fungsional melihat setiap ritual dalam agama memiliki signifikansi teologis, baik dari dimensi psikologis maupun sosial. Aspek-aspek teologis sebuah ritual keagamaan seringkali bisa ditarik benang merahnya dari simbol-simbol religius sebagai bahasa maknawiah. Pemaknaan terhadap simbol-simbol keagamaan tersebut sangat bergantung kepada kualitas dan arah performa ritual serta keadaan internal partisipan hingga sebuah ritual bisa ditujukan untuk "memuaskan" Tuhan atau kebutuhan spiritualnya sendiri.

mitos kedalam beberapa motifemsuntuk menentukan struktur mitos.

59 | P a g e 
Dalam konteks sosiologis, sebuah ritual juga merupakan manifestasi dari apa yang disebut oleh Durkheim sebagai "alat memperkuat solidaritas sosial" melalui performa dan pengabdian. Tradisi slametan merupakan contoh paling konkret dari ritual jenis ini sebagai alat untuk memperkuat keseimbangan masyarakat (social equilibrium), yakni menciptakan situasi rukun -setidaknya- di kalangan para partisipan.

\section{Malin Kundang ${ }^{8}:$ Kedurhakaan Pada Ibu Biologis dan Ibu Sosial}

erdapat beberapa variasi dalam
penceritaan mitos Malin Kundang
ditengah-tengah masyarakat namun konteks dan isi atau substansi dari cerita tidak berubah. Konteks sosial budayanya adalah Minangkabau pesisiran, dengan tokoh utama seorang ibu dan anak laki-laki serta sosok ayah yang absen yang menjadi motif perilaku para aktor serta isi cerita yang berakhir dengan sad ending.

Hubungan ibu dan anak laki-laki dalam kisah ini merupakan refleksi relasi inti dalam struktur sosial orang Minangkabau. Dalam masyarakat matrilinieal Minang kabau, posisi perempuan terutama saat sudah menjadi seorang ibu merupakan simpul relasi sosial yang penting. Ibu dapat menjadi kata penentu dan pemutus dalam banyak hal terkait dengan kehidupan anggota keluarga perinduannya. Posisi yang demikian penting, membuat perempuan secara ideal normatif sangat dihargai, dihormati dan dipatuhi dan sebaliknya juga perempuan dituntut untuk memenuhi peranperan sosial budaya normatifnya.

Malin Kundang juga adalah refleksi dari peran laki-laki dalam budaya Minangkabau yang harus mencari eksistensi dirinya dengan merantau sebagai ukuran 'kebergunaan' dirinya yang baru diakui jika ia buktikan melalui pencapaian di rantau. Merantau juga merupakan sebuah upaya mobilitas sosial yang dapat memperbaiki status dan kelas sosial seseorang dalam struktur masyarakat. Jika status sosial yang ascribed adalah genealogi, maka status sosial achieved dapat dilakukan seseorang

\footnotetext{
${ }^{8}$ https://dongengkakrico.wordpress.com/cerita/ce rita-rakyat-malin-kundang/
}

$60 \mid \mathbf{P}$ a g e melalui pencapaian2 prestatif yang memungkinkannya untuk naik kelas sosial.

Apa yang dilakukan oleh Malin Kundang dan ibunya adalah sebuah upaya untuk keluar dari kemiskinan, mambangkik batang tarandam dan memperbaiki status sosial keluarga mereka. Keberhasilan Malin Kundang di rantau adalah sebuah cerita tipikal ideal dari laki-laki Minangkabau yang mencari peruntungan di rantau. Keberha silan itu akan memberi kebanggaan pada keluarganya dan dapat meningkatkan penghargaan dari masyarakat. Namun yang terjadi dalam cerita Malin Kundang adalah anti tesis yang menolak pengakuang terhadap asal dan usulnya. Penolakan Malin Kundang terhadap ibunya mengguncang kosmologi tatanan nilai ideal dan terdalam dari kebudayaan Minangkabau. Kesalahan fatal yang tak dapat dimaafkan meskipun kemudian Malin Kundang berteriak meminta ampun.

Kondisi yang sangat tidak ideal ini tidak dapat diperbaiki dan jalan satu-satunya adalah hukuman dari 'langit' bagi Malin Kundang atas titah ibunya yang hatinya hancur karena penolakan anak yang disayanginya. Adalah Menarik untuk menganalisa mengapa cerita keberhasilan Malin Kundang disertai dengan tragedi penolakan terhadap ibunya sendiri yang notabene adalah asal usul identitasnya yang asli...?. Dalam cerita ini, tokoh ibu tidak hanya sebagai gambaran asal usul biologis dari Malin Kundang tapi juga adalah asal usul sosial dirinya. Nilai moral dari cerita tragedik dan sangat populer ini adalah bahwa orang tidak boleh mengingkari asal dan usulnya seberapapun tinggi penca paiannya. Identitas diri adalah 'bumi' tempat kaki berpijak dan jika ini diiingkari hukumannya sangat tidak terbayangkan karena menjadi batu adalah hukuman yang belum ada duanya.

\section{Sabai Nan Aluih dan Mangkutak Alam ${ }^{9}$ : Moral Keberanian dan Kepengecutan erita Sabai nan Aluih cukup terkenal}

$\mathrm{C}$ dan banyak diabadikan dalam kesenian kaba ${ }^{10}$ dan randai ${ }^{11}$

\footnotetext{
${ }^{9}$ http://histori.id/kisah-sabai-nan-aluih/

10 Kaba adalah genre sastra tradisional Minangkabau. Kata kaba sendiri berasal dari bahasa Arab khabar, yang sinonim dengan
}

Nilai Edukasi Mitos dan Relevansinya 
Berdasarkan karakter tokoh utama cerita terdapat 2 karakter penting yaitu Rajo Babandiang dan Sabai nan Aluih sebagai tokoh dengan karakter baik yang berani membela kehormatan diri meskipun nyawa menjadi tantangannya. Sementara, tokoh dengan karakter yang sebaliknya adalah Rajo Nan Panjang dan Mangkutak Alam. Rajo Nan Panjang adalah perwujudan karakter sombong dan merasa bahwa kekayaannya dapat mewujudkan semua keinginannya meskipun itu melanggar hak orang lain. la tidak segan memaksakan kehendaknya dengan mengancam dan memeras orang lain melalui kaki tangannya. Sementara Mangkutak Alam meskipun ia adalah saudara sekandung dengan Sabai, tapi memiliki karakter yang bertolak belakang dengan Sabai dan sangat penakut.

Moral utama cerita adalah soal keteguhan memelihara harga diri dan kehormatan diri yang harus dimiliki seseorang meskipun itu akan menjadi pertaruhan nyawa yang bertolak belakang dengan sifat mementingkan diri sendiri dan pengecut seperti yang diperlihatkan melalui tokoh Rajo Nan Panjang dan Mangkutak Alam. Meskipun dua tokoh utama protagonis dan antagonis akhirnya sama-sama mati namun nilai kematian keduanya sangatlah berbeda. Keteguhan sikap Rajo Babandiang yang akhirnya mati demi membela kehormatan anak gadisnya membuat kematiannya menjadi bermakna. Adapun keberanian Sabai Nan Aluih menuntut balas kematian Ayahandanya juga merupakan sikap yang patriotik. Keduanya menjadi acuan perilaku ideal bagi masyarakat

kata berita (Minangkabau: barito). Namun dalam peristilahan Minangkabau kedua kata ini dibedakan. Dalam segi cerita kaba mirip dengan hikayat atau cerita dalam Sastra Melayu.(wikipedia Indonesia)

${ }^{11}$ Randai adalah salah satu permainan tradisional di Minangkabau yang dimainkan secara berkelompok dengan membentuk lingkaran, kemudian melangkahkan kaki secara perlahan, sambil menyampaikan cerita dalam bentuk nyanyian secara bergantigantian. Randai menggabungkan seni lagu, musik, tari, drama dan silat menjadi satu. (wikipedia Indonesia)

Nilai Edukasi Mitos dan Relevansinya pendukung kebudayaan Minangkabau yang menjadi konteks dari cerita tersebut.

\section{Rancak $\mathrm{Di}$ Labuah $^{12}$ : Moral Konsep Pengendalian Diri}

A da beberapa tokoh yang disebutkan dalam kaba dan cerita ini, namun tokoh Rancak di Labuah atau yang aslinya bernama Buyuang Geleang adalah tokoh utama cerita. Cerita ini memang terutama menguraikan berbagai karakter manusia dan nama-nama yang digunakan dalam cerita secara eksplisit menunjukkan bermacam watak kepribadian manusia dan mengacu pada sifat dan fungsi. Simpul utama cerita berpusat pada Rancak di Labuah yang namanya secara etimologis memiliki arti sebagai 'indah di jalan' atau dalam pemaknaan simbolis adalah hanya indah atau bagus dari luar namun di dalamnya tidak indah atau tidak bagus. Merupakan sebuah ungkapan tentang sifat dan perilaku yang tidak jujur karena mencoba mengesankan citra baik namun sesungguhnya tidak demikian.

Cerita kemudian memaparkan bagaimana pola hidup tokoh Rancak di Labuah yang besar pasak dari pada tiang akhirnya membuatnya berhutang banyak dan mengakibatkan keluarga mereka yang sebenarnya sudah miskin menjadi bertambah miskin. Keadaan ini menya darkan Rancak Di Labuah akan nasehat yang sebelumnya sering disampaikan oleh ibunya namun diabaikannya. Perlahan ia mulai merubah sifat dan perilakunya dari malas bekerja menjadi lebih rajin mengerjakan tanpa pilih-pilih. la juga berhemat dan menabung guna membayar hutang-hutang yang telah dibuatnya. Rancak Di Labuah dikisahkan berhasil merubah keadaan buruk kembali menjadi baik bahkan ia kemudian mendapatkan panggilan baru yaitu Sutan Samparono yang artinya 'seorang laki-laki yang sempurna' dan kemudian diberi gelar Dt Naraco Laut Budi atau yang memiliki arti timbangan lautan budi'.

Moral utama dari cerita ini adalah pentingnya mengenali diri sendiri secara jujur sehingga mampu mengendalikan diri

\footnotetext{
${ }^{12}$ Abdurrahman Salman; http://abdurahmanpadang.blogspot.co.id/2011/11/makalahseminar-karakter-di-unv-bung.html
}

$61 \mid$ P a g e 
dan bersikap wajar dan tidak dibuat-buat. Perilaku yang tidak sesuai dengan keadaan diri yang sesungguhnya mendatangkan masalah dan musibah. Cerita juga menunjukkan bahwa selalu ada kesempatan untuk perubahan yanglebih baik asalkan berusaha dengan sungguh. Penghargaan yang sejati bukanlah dari tampilan fisik tapi datang dari kejujuran terhadap jati diri yang asli.

Secara lebih umum, cerita ini memiliki muatan moral dan sistim nilai ideal yang seharusnya dimiliki seseorang sebagai anggota masyarakat. Peran tokoh ibu Siti Jauhari dalam cerita ini merupakan sosok sentral yang memiliki peran penting dalam alur cerita, sebagai media untuk menyampaikan proses enkulturasi nilai budaya Minangkabau yang kadang-kadang tidak hanya bersifat filosofis tapi juga dogmatis.

Dalam versi cerita yang lebih lengkap, cerita Rancak di Labuah tidak hanya berisi gambaran tentang karakter baik buruk tokoh utama sebagai anggota masyarakat dan juga sebagai anak laki-laki, suami dan rang sumando. Juga diuraikan fungsi dan peran ideal anak perempuan dan peran sebagai istri dan ibu melalui ketokohan Siti Budiman. Peran ideal orangtua, mamak dan penghulu sesuai dengan budaya Minangkabau juga banyak diuraikan.

\section{Asal Usul Nama Minangkabau ${ }^{13}$ : Menang dengan Cerdik}

$\mathrm{M}$ oral utama dalam cerita ini adalah bahwa kekerasan tidak selalu jadi satu-satunya cara untuk bisa memenangkan sesuatu. Kemampuan berdiplomasi dan berunding merupakan ujud kecerdasan intelektual yang dapat menjadi faktor penentu dalam penyelesaian masalah. Dalam cerita juga diuraikan bahwa kebersamaan dan musyawarah juga dapat menjadi kekuatan sebuah kelompok masyarakat untuk bersama-sama memikirkan dan mencari jalan keluar dari sebuah permasalahan.

\footnotetext{
${ }^{13}$ Berbagai sumber
}

C. Nilai Edukasi Mitos dan Relevansinya dengan Penanaman Nilai pada Keluarga Minangkabau Kontemporer: Sebuah Konklusi

$\mathrm{M}$ itos yang terdapat dalam masya rakat Minangkabau memiliki struktur dan kandungan nilai yang fungsional untuk proses enkulturasi nilai-nilai tradisi kepada generasi baru guna memastikan budaya dan identitas keminangkabauan tetap lestari. Dalam konteks sosial yang niscaya memiliki karakteristik untuk berubah, pola pengasuhan anak juga mengalami pergeseran dan perubahan. Sehingga menarik untuk menelusuri apakah nilai-nilai yang terdapat dalam mitos masih memiliki kerelevansian dalam pengasuhan dan pendidikan anak oleh orang tua. Gagasan tentang bagaimana tingkat kerelevansian mitos dengan kehidupan masa kini menarik untuk ditelusuri terutama untuk memahami seberapa bergesernya pranata, pola interaksi dan sistim nilai dalam pengasuhan anak ditengah kenyataan bahwa mitos muncul pada setiap masyarakat dan budaya adalah dalam memenuhi kebutuhan masyarakat bersangkutan untuk menjawab berbagai persoalan yang belum mereka ketahui jawabannya.

Mitos adalah sebuah teks dan sebagai sebuah teks dia mengandung makna dari inti kebudayaan. Melalui pemahaman mendalam pada mekanisme artikulasinya, latar pemikiran sebuah kebudayaan dapat diketahui. Mitos juga memiliki struktur 2 sisi yaitu struktur permukaan (surface structure) yang terdapat pada lapisan terluar, dan struktur dalam atau struktur inti (deep structure) yang memuat konten sejati dibalik suatu tindakan kebudayaan $^{14}$.

Pengasuhan anak atau populer dikenal dengan istilah parenting adalah rangkaian perilaku yang secara normatif diwarnai oleh kehangatan, sensitif, penuh penerimaan, bersifat resiprokal, pengertian dan respon yang tepat pada kebutuhan anak $^{15}$. Perilaku dan situasi normatif - positif ini akan menghasilkan apa yang dimaksud dengan "kelekatan" (attachment) dan akan membangun mentalitas dengan self esteem yang mampu menghargai secara positif diri

\footnotetext{
${ }^{14}$ Ahimsa-Putra, 1999 hal 67-71

${ }^{15}$ Garbarino \& Benn, 1992 dalam Budi Andayani, Juni 2004.
}

Nilai Edukasi Mitos dan Relevansinya 
sendiri yang pada gilirannya akan mendukung terciptanya kemampuan yang baik dalam penyesuaian melalui pengembangan potensi dan kompetensi sosial ${ }^{16}$.

Dalam kajian psikologi anak dikenal 4 pola pengasuhan yaitu otoriter, neglectful, indulgent dan authoritative ${ }^{17}$. Pola otoriter adalah pengasuhan yang kaku, diktator dan memaksa anak untuk selalu mengikuti perintah orangtua. Pola neglectful adalah pola pengasuhan dimana orangtua tidak mau terlibat dan tidak mau pula terlalu memedulikan kehidupan anak. Pola indulgent adalah sikap pengasuhan yang cenderung membiarkan anak melakukan apa saja sesuai keinginan mereka sedngkan pola authoritative adalah perilaku pengasuhan yang mendorong anak untuk mandiri dengan tetap menetapkan batas dan kendali. Rangkaian perilaku pengasuhan dalam pola ini diserta dengan sikap hangat, welas asih, menerima latar belakang tindakan anak sembari menjelaskan pada anak tentang dukungan dari orangtua jika tindakannya konstruktif.

\section{Struktur Umum dan Nilai Utama Mitos}

Struktur umum dari ke empat mitos yang di analisis adalah bahwa kemenangan pada akhirnya selalu menjadi milik kebaikan dan sebaliknya kehancuran adalah buah dari kejahatan. Kelas sosial nampaknya juga dapat ditentukan oleh kekayaan namun kemuliaan dan penghargaan murni tidak semata berdasarkan pada kekayaan tapi pada kebaikan perilaku. Dalam mitos selalu ada tokoh protagonis dicirikan dengan sifat sabar, dan selalu berpihak pada nilai-nilai kebaikan dan tokoh antagonis yang dicirikan dengan sombong dan semena-mena. Akhir cerita dari 4 mitos ini ditutup dengan menangnya kebaikan. Ketokohan perempuan juga menonjol dalam ke empat mitos terutama figur ibu (Malin Kundang dan Rancak Di Labuah) sementara dalam dua mitos lainnya, perempuan memainkan peran cerdas dan berani dalam kebenaran yang tak kalah penting ( Sabai Nan Aluih dan Asal-usul Nama Minangkabau).

\footnotetext{
${ }^{16}$ i.b.i.d

${ }^{17}$ Diana Baumrind dalam Else Liliani, Bibliografi Psikologi Anak UNY, 2007
}

Selanjutnya norma umum lainnya terkait dengan kemiskinan dan kekayaan, dimana nilai pertama adalah kerja keras merupakan cara terbaik untuk keluar dari kemiskinan (Malin Kundang dan Rancak Di Labuah) dan sebaliknya kekayaan juga bukan alasan untuk bersikap jumawa dan sombong (Malin Kundang dan Sabai Nan Aluih) apalagi jika sampai mengingkari identitas dan jati diri (Malin Kundang dan Sabai Nan Aluih). Nilai penting lainnya adalah bahwa harga diri adalah hal yang harus diperjuangkan meskipun itu taruhannya nyawa (Sabai Nan Aluih), nilai kecerdikan dan keberanian dengan paduan yang tepat dapat memenangkan pertarungan tanpa mengorbankan nyawa karena dibarengi dengan kemampuan berunding (diplomasi) (Asal usul Nama Nagari Minangkabau).

\section{Relevansi Mitos dalam Pengasuhan Anak Pada Keluarga Minangkabau Kontemporer \\ Mengacu pada pola pengasuhan} menurut Diana Baumrind dan mengacu pula pada data lapangan hasil pengamatan 5 keluarga Minangkabau dapat disimpulkan ciri pola pengasuhan indulgent dan neglectful cenderung ditemukan pada keluarga Amri, Jang dan Wan dimana ada kecenderungan membiarkan anak melakukan apa saja berbarengan dengan kurangnya kepedulian orangtua pada pertumbuhan anak. Sedangkan ciri pola otoriter dan juga ciri autoritatif dimana orangtua lebih mendominasi hubungan anak-orangtua berbarengan dengan memberi dorongan dan ruang bagi anak untuk tumbuh mandiri sesuai dengan keinginan yang dikontrol oleh orang tua.

Apakah nilai-nilai edukasi dalam mitos masih relevan dalam pola pengasuhan anak di keluarga Minangkabau hari ini...? dari data 5 keluarga yang di amati, cerita mitos itu sendiri tidak lagi hadir dalam kehidupan keseharian kelima keluarga ini namun secara substansi, nilainilai ideal normatif masih dikenali. Mitos Malin Kundang paling populer diingat oleh semua informan, sedang 4 cerita lainnya tidak begitu mereka ingat lagi terutama bagi anak-anak yang bahkan tidak mengenali cerita mitos tersebut. Meskipun semua keluarga setuju dengan nilai-nilai normatif 
yang terkandung dalam mitos tapi 3 keluarga diantaranya (Amri, Jang dan Wan) mengatakan bahwa nilai-nilai tersebut tidak dapat ditemukan dalam kehidupan seharihari sedangkan 2 keluarga lainnya (Syafril dan Zal) masih percaya dengan perlunya nilai-nilai tersebut ditanamkan dalam keluarga meskipun transfer nilai tidak lagi dimediasi oleh mitos.

\section{Kesimpulan:}

idak dapat dipungkiri, kehadiran pola
komunikasi melalui media baru
bersamaan dengan ditemukannya sarana dan saluran komunikasi memberi pengaruh yang signifikan terhadap interaksi komunikasi antar indvidu dalam masyarakat. Merujuk pada definisi Wikipedia, media baru merupakan sebuah terminologi untuk menjelaskan konvergensi antara tekhnologi komunikasi digital yang terkomputerisasi serta terhubung ke dalam jaringan. Contoh dari media yang sangat merepresentasikan media baru adalah internet. Media baru memungkinkan komunikasi dalam jejaring sosial melalui berbagai fasilitas seperti blog, facebook, twitter, instagram hingga path.

Penggunaan media baru seperti yang dimaksud ditemukan pada lima keluarga yang diamati. Meskipun penelitian ini tidak mencermati hubungan antara variabel penggunaan media baru dengan pola asuh dalam keluarga, namun dalam pengamatan awal terlihat bahwa variabel ini memberi pengaruh yang cukup menge sankan. Kelima keluarga ini memiliki ciri yang sama yaitu para orangtua samasekali tidak melek internet sementara anak-anak sudah mengenali media ini dan beberapa orang anak informan termasuk pengguna aktif.

Efek dan dampak perkembangan media baru ini berpengaruh langsung pada perilaku komunikasi masyarakat dalam komunitas. Meskipun penggunaan media baru ini dapat berefek positif karena dapat membuka secara luas akses terhadap informasi, media baru juga dapat menjadi sebagai agen pembawa nilai-nilai budaya dan menghidupkan kembali nilai tradisi yang mulai hilang. Namun ini bukan tanpa dampak negatif. Selanjutnya dampak negatif dari kehadiran media baru ini menurut Gunter and Harrison (1998) antara lain, yaitu:

- Merusak Tatanan Masyarakat
Tatanan masyarakat akan rusak ketika pengaruh kehadiran media baru ini sudah mengubah pola perilaku masyarakat dalam komuni kasi sehari-harinya.

- Merendahkan Warisan Budaya Selain dapat membawa kembali nilai tradisional yang telah hilang, keha diran media baru juga akan dapat merendahkan warisan budaya yang telah ada ketika pengaruhnya telah mendarah daging dalam diri masingmasing individu dimana pengaruh yang berupa informasi itu datang dari budaya lain yang tidak sesuai dengan budaya yang seharusnya ada dalam audiens yang ber sangkutan.

- Deformasi Pikiran Kaum Muda

Kehadiran media baru ini dapat merubah bentuk pikiran-pikiran muda menjadi lebih berorientasi kepada sifat kapitalisme akibat dari konten-konten yang terdapat dalam media baru ini.

- Modernisasi, Industrialisasi, Urbani sasi dan Transportasi

Merusak Modernisasi ketika penga ruh media baru ini hanya membawa masyarakatnya ke kehidupan Hedo nisme dan melupakan sifat asli budayanya. Merusak Industrialisasi ketika pengaruh media ini hanya berorientasi kepada kemajuan dibidang industri tanpa memperha tikan efeknya pada lingku ngan. Proses Urbanisasi menjadi hal yang buruk ketika media baru menyam paikan informasi yang terlalu melebih-lebihkan keadaan di sebuah kota yang mengakibatkan para penduduk desa tertarik untuk mengadu nasib di kota besar namun mereka tidak mempunyai kemam puan yang harus dimiliki ketika harus berpindah ke kota.Trans portasi akan semakin buruk ketika sebuah kota semakin penuh dengan manusia akibat dari Urbanisasi yang buruk.

- Kualitas Perbincangan

Kualitas Perbincangan secara tatap muka akan menurun ketika masya rakat sudah terbiasa berkomunikasi secara virtual dengan orang lain sehingga saat bertatap muka

Nilai Edukasi Mitos dan Relevansinya 
masyarakat akan lupa dengan aspek-aspek komunikasi antarper sonal yang semestinya.

- Propaganda dan Mobilisasi Media ini seiring berjalannya waktu ditakuti akan dijadikan sebagai alat potensial untuk propaganda politik dan mobilisasi kepentingan-kepen tingan dari para penguasa.

Pengaruh penggunaan media baru oleh anak diasumsikan merubah perilaku anak karena hubungan anak dalam peer group menjadi sangat intens dan disaat bersamaan hubungan dengan orangtua merenggang dan pada akhirnya transfer nilai-nilai akan terhambat. Komunitas virtual dimana anak terlibat interaksi di dalamnya sangat bertentangan dengan ciri masyarakat organik dimana orangtua atau anggota masyarakat yang lebih senior hidup. Eksistensi komunitas organik lebih meng gambarkan suatu kelompok yang benarbenar nampak dalam kehidupan nyata. Sebaliknya dengan komunitas virtual sehingga fragmentasi antara keduanya dapat melebar dan potensial menyimpan masalah-masalah sosial.

\section{Daftar Pustaka}

Adiwikarta, 1998. Sosiologi Pendidikan: Isyu dan Hipotesis tentang Hubungan Pendidikan dengan Masyarakat. Jakarta: P2LPTK

Ahimsa, Putra. 1999. Strukturalisme Levi Strauss: Mitos dan Karya Sastra. Yogyakarta. Galang Press

1998. Levi Strauss, Orang-orag PKI, Nalar Jawa, dan Sosok Umar Kayam: Telaah Struktural-Hermenuetik Dongeng Etnografis Umar Kayam dalam Umar Kayam dalam Jaring Semiotik (ed. Aprinus Salam). Yogyakarta: Pustaka Pelajar.

Andayani, Budi. 2004. Tinjauan Pendekatan Ekologi Tentang Perilaku Pengasuhan Orangtua. Buletin Psikologi, tahun XII No.01 Juni 2004

Campbell, Joseph,2014 The Hero's Journey : Joseph Campbell on His Life and Work (The Collected Works of Joseph Campbell), New World Library, California.

Hartley. L.P, 1953. the Go - Between. Hamish Hamilton. England

Liliani, Else. 2008. Membongkar Kesalahan Pola Asuh Anak dalam Mitos-mitos di Indonesia. Bibliography Psikologi Anak, FBS Universitas Negeri Yogyakarta

Nurgiyantoro, B, 2005. Sastra Anak: Pengantar Pemahaman Dunia Anak. Yogyakarta; Gadjah Mada University Press.

Saifuddin, A. F 2005. Antropologi Kontemporer: Suatu Pengantar Kritis Mengenai Paradigma. Jakarta. Prenada Media 